\title{
Relationship between social supports and Anxiety of mothers treating child with cancer
}

\author{
Umi Hanik Fetriyah ${ }^{1 *}$ \\ ${ }^{1}$ Departement of Science Nursing, STIKES Sari Mulia, Banjarmasin Indonesia \\ *umi_hanik_f04@yahoo.co.id \\ Sri Mulatsih ${ }^{2}$ \\ ${ }^{2}$ Pediatric Oncology Department of General Hospital Sardjito, Yogyakarta Indonesia \\ srimulatsih@gmail.com \\ Heny Suseani Pangastuti ${ }^{3}$ \\ ${ }^{3}$ Master of Nursing Program Faculty of Medicine, Gadjah Mada University, Yogyakarta Indonesia \\ Henysp@gmail.com
}

\begin{abstract}
Objective: To analyze the association between social support and mother's anxiety, the category of social support received, needed by mother treating the child with cancer.

Method: This study non-experimental approach sequential explanatory mixed method strategy. Analytical correlation cross-sectional study 49 mothers treating the child with cancer in Installing Child Health Hospital Dr. Sardjito selected by consecutive sampling, qualitative exploration 9 informants selected by purposive sampling. The research instrument using Social Support Questionnaire, Pediatric Inventory for Parents, in-depth interview guide. Analysis using Pearson and content analysis.

Results: Mother's worried long-term effects of cancer $(55,10 \%)$. The correlation number of support persons with mother's anxiety $(\mathrm{r}=0.166 ; \mathrm{p}=0.253)$, correlation between satisfaction received support with mother's anxiety $(r=-0.330 ; p=0.021)$. Findings are mothers who less social support are the risk of severe anxiety, mothers get meaningful support and needed such as information and emotional support from family, neighbors, fellow who had the child with cancer, health workers. Instrumental and appraisal support from families, neighbors, friend, health workers. The mother states information support is important from the health worker, the fellow who had the child with cancer it makes to adapt, accept child's condition, emotional support from family make mother felt more confident treating child's.

Conclusion: There is no correlation number of support persons and mother's anxiety. There is a significant negative correlation satisfaction received support and mother's anxiety. Category of support received, needed by mother especially information, emotional support.
\end{abstract}

Keywords: anxiety, cancer, mixed methods, mothers treating child, social support 


\section{INTRODUCTION}

The incidence of cancer is increasing, if not controlled, an estimated 26 million people will suffer from cancer and 17 million died of cancer in 2030 is expected to occur more rapidly in poor and developing countries [1]. Two-thirds of cancer patients in the world are in countries that are developing [2], including Indonesia. Special Region of Yogyakarta is a city which has a prevalence of cancer at all ages at a maximum of 4.1 per 1000 population, increased cancer prevalence $\geq 15$ age - 24 years at 0.6 per 1000 [3].

Families of the child diagnosed with cancer often suffer distress associated with childhood diseases, especially the parents. Long treatment and care of cancer in child result in family economic factors [4], other impacts felt by child and parents that depression and anxiety [5, 6]. Mothers reported significantly higher levels of stress than fathers $(p<0.001)$ [7]. Anxiety needs to be addressed because of the anxiety that extends contribute to the quality of life, interfering with the ability of families in emotional and social functioning [8].

Social support can affect the mother of a child diagnosed with cancer by increasing the perception of control, selfcontrol and reduce mother anxiety. The reduction of anxiety, feelings of hopelessness and helplessness improve health status [9]. The study states that the parents of the child with cancer, in general, confirm the relationship between social support and well-being expressed with lower levels of anxiety and depression [10].

One of the service child health that can be accessed at General Hospital Dr. Sardjito the inpatient child with hematooncology superior service. This research is expected to be useful for health personnel in identifying anxiety and improve the provision of social support that is appropriate for mother treating the child with cancer as well as.

\section{RESEARCH METHODS}

Observational research using a mixed method approach sequential explanatory strategy, the first stage of the second phase of quantitative research and qualitative [11]. Data collection was performed in Installing Child Health (ICH) Dr. Sardjito Hospital ward Estella 1 and Estella 2 September-October 2014 after approval by the Ethics Committee of the Faculty of Medicine, Gadjah Mada University, Department of Education and Training General Hospital Dr. Sardjito and research subjects. A quantitative study was a cross-sectional design consecutive sampling method [12]. Affordable 
population in this study were all mothers treating for the child diagnosed with cancer and received treatment, care in $\mathrm{ICH}$ General Hospital Dr. Sardjito. The population of the child with cancer at $\mathrm{ICH}$ General Hospital Sardjito is not known, then the formula for determining the number of samples obtained using a large proportion of the population [13]. The sample obtained 49 respondents are not taken at random. The second phase of the exploratory qualitative study, purposive sampling method [14], up to the saturation values obtained 9 informants were taken to meet certain criteria such as having extreme values results of the quantitative data.

Data were collected to obtain the data characteristics of the respondents, social support, and anxiety. Social support was measured using a questionnaire Social Support Questionnaire (SSQ) [15] (number of support persons, satisfaction with support) and the Pediatric Inventory for Parents (PIP) [16] to measure anxiety variables. Cronbach Alpha value SSQ results of 0.753 and PIP Cronbach Alpha of 0.745 . Interpretation of the acquisition value of SSQ and PIP in the interval scale. Qualitative data collection was used indepth interviews.

Quantitative data analysis using univariate analysis by describing the frequency distribution and percentage, characteristics of respondents of social support and anxiety [12]. Bivariate analysis using Pearson correlation test, a significance level of 5\%. Qualitative data analysis involves three stages (data reduction, data display, and drawing, verifying conclusions) [17].

\section{RESULTS}

a. Characteristics of respondents

Table 1. Frequency Distribution Characteristics of Respondents ( $\mathrm{n}=49)$

\begin{tabular}{lcc}
\hline $\begin{array}{c}\text { Characteristics of } \\
\text { Respondents }\end{array}$ & $\begin{array}{c}\text { Frequency } \\
\text { (f) }\end{array}$ & $\begin{array}{c}\text { Percentage } \\
(\%)\end{array}$ \\
\hline Education level & & \\
$\quad$ Elementary school & 9 & $18,37 \%$ \\
Yunior High School & 14 & $28,57 \%$ \\
$\quad$ Senior High School & 21 & $42,86 \%$ \\
Academy & 5 & $10,20 \%$ \\
\hline Employment & & \\
$\quad$ Does not work & 41 & $83,67 \%$ \\
$\quad$ (housewives) & & \\
Work (employe) & 8 & $16,33 \%$ \\
\hline $\begin{array}{l}\text { Distance diagnosed } \\
\text { with childhood cancer }\end{array}$ & & \\
research months & 24 & $48,98 \%$ \\
$<3$ months & 14 & $28,57 \%$ \\
3-12 cancer & 11 & $22,45 \%$ \\
$\quad$ 12 months & & \\
\hline Type of in child & & \\
treatment in & & \\
chemotherapy & 49 & 0 \\
surgery & 0 & 0 \\
radiotherapy & 0 & 0 \\
combination & 0 & \\
\hline
\end{tabular}

Source: Primary Data

Based on Table 1 are known most respondents are past high school educated mothers were 21 (42.86\%), does not work or a housewife as many as 41 people (83.67\%), having a child diagnosed with cancer within a period of $<3$ months of 24 people $(48.98 \%)$, all child undergoing chemotherapy respondents as many as 49 people (100\%). 
b. Relationship between Social Support with Anxiety

Table 2. Relationship of Social Support Viewed from Aspect The number of support persons and The Satisfaction Received Support with Anxiety Respondents $(\mathrm{n}=49)$

\begin{tabular}{lccc}
\multicolumn{4}{c}{ Anxiety Respondents $(\mathrm{n}=49)$} \\
$\begin{array}{l}\text { The Independent } \\
\text { Variable }\end{array}$ & $\begin{array}{c}\text { Dependent } \\
\text { Variable }\end{array}$ & $\begin{array}{c}\text { Correlation } \\
\text { Internal } \\
(\mathrm{r})\end{array}$ & $\mathrm{p}$-value \\
\hline $\begin{array}{l}\text { The number of } \\
\text { support persons }\end{array}$ & Anxiety & 0,166 & 0,253 \\
& & &
\end{tabular}

\begin{tabular}{llll}
\hline The satisfaction & Anxiety & $-0,330$ & 0,021
\end{tabular}
received

support

Source: Primary Data

Based on Table 2 shows no relationship between the number of support person with mother's anxiety indicated the value of $\mathrm{p}=0.253$ and correlation internal $(r)=0,166$ or it can be said that the higher the number of support person did not show the mother's anxiety getting lower. The relationship between the satisfaction received support with mother's anxiety is a significance value of $\mathrm{p}=0.021$ and correlation internal $(\mathrm{r})=-$ 0.330 so it can be interpreted the higher satisfaction received support then the mother's anxiety getting lower.

c. The category of support received, meaningful and needs by the mother in treating the child with cancer.

Mothers said that the husband, sibling, extended family, friends, co-workers, neighbors and fellow friends who have children with cancer and undergoing treatment \& care providing support information such notify and advise on foods consumed by children to avoid such foods with preservatives, a provider of blood donors, alternative medicine, the effects of chemotherapy, the treatment of children fever, mouth sores, alternative medicine and shelter availability, so that more mothers feel ready to face the possibility that occurs in children, reducing anxiety in treating children with cancer. The help of information is also taken into consideration the mother in the treatment of children with cancer.

Mothers received suggestions, advice on medication and treatment of cancer in children from the health worker, it makes the mother seeks to adapt and accept her medical condition as a manifested informant:

“...memang dokternya sudah bilang, dampaknya (kemoterapi) seperti apa, nantinya....ya itulah yang seharus terjadi, ya saya memakluminya kondisi anak saya" (Informant 2).

The majority of mothers felt very pleased to receive support information from the friends who both have children with cancer and health workers, which support the information obtained is the mother can provide reinforcement and decrease anxiety in treating children with cancer as revealed by the following informant 7 : 


\section{“...teman itu....yang sama (memiliki anak) penyakit kanker jadi saling menguatkan....pengetahuanlah tentang penyakit ini (anaknya.)" (Informant 7)}

The informant stated that in addition to the help information, they also receive emotional support they receive, meaningful and necessary for the care of children with cancer were obtained from the husband, sibling, extended family, friends, neighbors, coworkers, health workers. Emotional support informants get especially from a spouse or the husband and extended family. the form of emotional support given by the husband, sibling and family are generally in the form of attention, affection, caring, comforting, want to understand the attitudes, empathy, the attitude would hear complaints, directed to be submissive to God in the face of events regarding his health condition.

Most of the mothers feel very satisfied accepts forms of emotional support from the husband, extended family, friends, neighbors, fellow friends who have children with cancer and undergoing treatment \& care, health workers. A form of emotional support received by the mother felt unable to make the mother feel more confident in caring for children with cancer as the narrative informants 4:

"Dipeluk, dibelai, diberi
semangat, sabar dalam
menghadapi ini, kita hidup berdua
saja (suami)... bisa merilekan
pikiran ini"(Informant 4)

Most of the mothers said they were satisfied to receive instrumental support from extended family, neighbors, friends, and co-workers, for example, there is help bring souvenirs, send toys to children, give aid money, seek treatment room at the Hospital for children, it can help reduce the burden economy and facilitate mothers in treatment to care the children.

Most of the mothers said they were satisfied to receive instrumental support from health workers. Mother felt provided assistance health workers consisting of doctors, nurses, nutritionists and psychologists are perceived meaningful and needed a mother in caring for children with cancer because it gives a new hope for the condition of his health and reduces maternal anxiety in treating children with cancer. Assistance provided health workers such as checking the condition of the child's health, providing care, collaborate with other healthcare teams.

Most of the mothers also expressed feeling appreciated from people around mainly from the husband, large families 
and health professionals in the form of an attitude of blaming the mother on the health conditions of children, listen and respect his opinion, appreciate the ideas and actions taken mothers in caring for children with cancer. The informant also confirmed that the means and the need for aid because mothers make yourself feel meaningful and considered whereabouts.

The mother gets meaningful support and needed, such as information and emotional support from family, neighbors, coworkers, fellow friends who have children with cancer, health workers. Instrumental supports and appraisal from families, neighbors, friend, health workers.

\section{DISCUSSION}

The results showed that there was no relationship between the level of education, occupation mothers with maternal anxiety. Based on the results of a systematic literature review of research on the psychosocial impact of childhood cancer in the elderly are found in general aspects of demographic characteristics such as parental education level, socioeconomic status, social and demographic variables are not associated with psychological conditions parents better or worse [18]. The results showed no significant negative correlation between the number support persons with anxiety experienced by mothers ( $\mathrm{p}=$ 0.253). The results are consistent with Pakenham \& Bursnall (2005) research on the relationship number support persons with anxiety in mothers of the child with multiple sclerosis $(p>0,05)$ showed no significant negative correlation between the number persons support and mother's anxiety.

Based on the results of the study are also the majority of respondents are given a lot of social support derived from primary sources (husband, extended family), secondary (friends, neighbors, official mate), tarsier (health workers and organization/government) it makes large number support person. Mother assume that the disease of cancer in a child is a stressor (stimulus) threatening her, so she felt uneasy, very tense, worried, scared, anxious face situations in the process of treatment and care of child, although quite a lot about the number of mothers who give assistance, support and help him but the mother remains shrouded in treating anxiety in child diagnosed with cancer.

Social support to be considered in addition to the amount of support is more important is the quality of support received support in the form of satisfaction, which is a support satisfaction of psychological assessment based on the mother's perception of the support given to 
the mother in the care of child with cancer useful perceived or not, as needed or no. According to Cohen and Syme (1985) that in terms of the quality of social support in the form of satisfaction is greater than the effect of social support in terms of quantity (number of people). Pearson statistical test results that the higher the satisfaction of mothers receiving support, the lower the anxiety he felt $(p<0.05)$, whereas the lower the satisfaction of mothers receiving support, the lower the anxiety. The results are consistent with research Norberg, Lindbald \& Boman (2006) states that mothers obtain a low level of social support cause the mother to feel more depressed and anxious. The results previous research that lower the social support satisfaction one receives the most likely to have psychological distress such as depression and anxiety constant high with $\mathrm{p}<0.001$ [21].

The form of social support from people around the mother in the care of children with cancer have been received, meaningful or memorable and necessary for the mother namely form of information support, emotional, instrumental and appreciation. Consultation health problems are expected to reduce maternal anxiety and help the mother to live up to and right to help his healing process. According Smeth (1994) that support the information would be useful if people lack the knowledge and skills about the problems they experienced. Support information is also helpful to see how a person behaves and act in the face of situations that burden [9].

The study confirms that a lack of social support is important to risk factors that contribute to the well-being of mothers treating a child with cancer and a bad effect on interpersonal relationships and the ability to control himself in the care of his son. Some of these studies explain the concept of the direct effect of social support the hypothesis that mother social support received beneficial to the welfare and health regardless of the amount of tension experienced by the mother [22]. The concept of hypothesis buffer (Buffering Hypothesis) according to Cohen and Syme (1985) that social support is beneficial to the health and welfare of mothers treating for the child with cancer by protecting the mother against the negative effects of severe stress level for example in the form of severe anxiety. The effects of social support are not always can reduce a person's distress because of social support is given by others to someone, not all support the perceived benefit to a person, a match between the needs of the type of support (forms or category of support) available [23]. According to 
Norberg \& Boman (2007) that support perceived mother is an important buffer against the distress he felt, there is a complex relationship between perceived support and distress such as anxiety, depression which indicates that maintaining the perceived support the mother should be the primary goal of nursing and psychosocial care of parents from children with cancer.

The results of this study support previous research that greater anxiety because in addition to thinking about the care and treatment of children [25]. Assistance information received, meaningful and needed by mothers treating child with cancer such as advice, suggestions, explanations about the cancer and prognosis, the treatment and care, side effects of chemotherapy treatment, prevention of infection, bleeding handling of the skin and mouth area, ways of handling fever or heat, handling thrush, a provider of blood donors, nutritional needs, how to feeding, the estimated cost of treatment, and the availability of health insurance (named BPJS), alternative medicine and the availability of temporary homestay/ shelter. She also stated that the emotional support of her husband, family, neighbors, friends, and co-workers have received and are very important for mothers treating for the child with cancer.
Support is one of their coping mechanisms are used throughout the period of cancer at diagnosis, medication, after medication period.

The support is very important information for the mother in the care of children with cancer, especially from health personnel and the fellow who had a child diagnosed with cancer and undergoing cancer treatment procedures regarding treatment, side effects of chemotherapy treatment. These results are supported by a research Fletcher (2011) where the mother praised the support from a health information related to medication, giving input and feedback from parents who have the same condition with their children this can really help in treating children with cancer. The research findings Norberg \& Boman (2008) states the intervention and support of healthcare professionals must be able to provide information support needs, the participation of parents in care to maintain a sense of control and function of the role of parents in the care of children with cancer.

Most of the mothers revealed receiving instrumental aid in the form of practical aid, material, services and time given by the husband, family, neighbors, friends and health professionals received and perceived meaningful or memorable 
and it takes a mother in caring for children with cancer. Mother is also expressed support of instrumental the provision of food from neighbors, help health workers on them and know that mothers have people around who always reliable when needed his help [26]. Mother also worried and think of the daily duties of housewives [25].

The results of this study supported the Al-Momani (2013) stated for healthcare professionals to reduce the stress of mothers through diagnostic procedures provide specific information should be made for the child and emotional support. In line with the results of qualitative research Fletcher (2011) stated that the mother revealed the importance of such forms of emotional support feel loved, cared for by family, friends, coworkers. Information and emotional support are inadequate can lead to parents who care for the child diagnosed with cancer using fewer coping strategies that can lead to maladjustment [28].

A literature review by Pedro et al (2008) on social support families from children with cancer states that healthcare professionals should provide access to various forms of support to children with cancer and their families, recognizes the need for family support, because it is very important for planning integral and adequate nursing care and medical care. The support received by the mother will have to mean, it takes when it receives the support beneficial, according to the conditions, a situation at hand. The support received by a person and needs depending on the situation that suppresses or nerves [30].

The main assessment support husbands and health workers in the form of an attitude of blaming the mother on the health conditions of the child, appreciate, feedback, support helps mothers in adjustment to his health condition, the mother having people around who always reliable when needed assistance [24].

Suggestion for health workers provides support for the impact of cancer information, treatment and care by using simple language, clear and precise, emotional support using family approach, which is expected to reduce the feeling confused, anxious mothers and families in treating for their child.

\section{CONCLUSION}

There is no correlation number of support persons and mother's anxiety. There is a significant negative correlation satisfaction received support and mother's anxiety. Category of support received and needed mother especially information and emotional support. 


\section{ACKNOWLEDGEMENT}

I am very grateful to the Head of Installing Child Health Hospital Dr. Sardjito, STIKES Sari Mulia and Gadjah Mada University who has given permission to conduct research, and thanks to who has given permission and place to conduct this research.

\section{REFERENCES}

[1]. World Health Organization (2008). Cancer control and knowledge into action: who guide for effective programmes. Switzerland: Department of Chronic Diseases and Health Promotion World Health Organization.

[2]. International Union Against Cancer (2009).Global Action Against Cancer. Geneva: International Union Against Cancer and the World Health Organization.

[3]. Riset kesehatan dasar/RISKESDAS (2013). Basic health research 2013. Jakarta: Research and Development Agency for Health, Ministry of Health.

[4]. Miedema, B., Easley, J., Fortin, P., Hamilton, R., Mathews, M. (2008). The economic impact on families when a child is Diagnosed with Cancer. Current Oncology,15, 813.

[5]. Norberg, A.L., Boman, K.K. (2008). Parent distress in childhood cancer: a Comparison evaluation of posttraumatic stress symptoms, depression and anxiety. Acta Oncology, 47, 267-274.
[6]. Toro, A.J.D. (2008). Psychological impact of childhood cancer: public interest government relations office. The American Psychological Association, 202, 336.

[7]. Masa'Deh, R., Collier, J. \& Hall, C. (2012). Parental stress when treating for a child with cancer in Jordan: a cross-sectional survey. BioMed Central: Health and Quality of Life Outcomes, 10, 1-7.

[8]. World Health Organization (1996). Creating supportive environments for health: Stories from a third international conference on health promotion Sundsvall, Sweden. Geneva: Department of Chronic Diseases and Health Promotion World Health Organization.

[9]. Cohen, S. \& Syme, S.L. (1985). Issues in the study and application of social support in: social support and health, California Academic Press.

[10]. Dockerty, J.D., Williams, S.M., Mc Gee, R., Skegg, D.C. (2000). Impact of childhood cancer on the mental health of parents. Med Pediatr Oncol, 35, 475-483.

[11]. Cresswell, J.W. \& Clark, V.L.P. (2011). Designing and conducting mixed methods research. United States of America: SAGE publication Ltd.

[12]. Sastroasmoro, S. \& Ismael, S. (2008). Fundamentals of clinical research methodology. 3rd Edition. Jakarta: Sagung Seto.

[13]. Lemeshow, S., Hosmer Jr. D.W., Klar, J., Lwanga, S.K. (1997). (edition of Indonesian: Sample size 
in health research). Yogyakarta. Gadjah Mada University Press.

[14]. Cresswell, J.W. 2008, Research design: qualitative, quantitative, and mixed methods approach, $3 \mathrm{rd}$ ed, Sage Publication. California.

[15]. Sarason, I.G., Levine, H.M., Basham, R.B., Sarason, B.R. (1983). Assessing social support: the social support questionnaire. Journal of Personality and Social Psychology, 44, 127-139.

[16]. Streisand, R., Braniecki, S., Tercyak, K.P., Kazak, A.E. (2001). Childhood illness-related parenting stress: the pediatric inventory for parents. Journal of Pediatric Psychology, 26,155-162.

[17]. Miles, M.B. \& Huberman, A.M. (1994). Qualitative data analysis. 2nd ed. California: SAGE Publications Inc.

[18]. Kohlsdorf, M. (2012). Psychosocial impact on parents of pediatric cancer: a literature review. Paideia, 22, 119-129.

[19]. Pakenham, K.I. \& Bursnall, B. (2006). Relations between social support, appraisal and coping and both positive and negative outcomes for children of a parent with multiple sclerosis and comparisons with children of healthy parents. Clinical Rehabilitation, 20, 709-723.

[20]. Norberg, A.L., Lindblad, F., \& Boman, K.K. (2006). The supportseeking perceived support, and anxiety in mothers and fathers of child's cancer after treatment. Psycho-Oncology, 15, 335-343.
[21]. Dunn, J., Kay Ng, S., Holland, J., Aitken, J., Youl, P., Baade, PD, et al (2013). Trajectories of psychological distress after colorectal cancer. PsychoOncology, 22, 1759-1765.

[22]. Smet, B. (1994). Health psychology, Jakarta : PT.Gramedia Widiasarana Indonesia.

[23]. Taylor, S.E. (2006). Health psychology. 6 th ed. New York: Mc Graw Hill International Edition.

[24]. Norberg, A.L., Boman, K.K. (2007). Parents' perceptions of support when a child has cancer: a longitudinal perspective, Journal of Cancer Nursing, 30, 294-301.

[25]. Perz, J., Ussher, J.M., Butow, P., Wain, G. (2011). Gender differences in cancer carer psychological distress: an analysis of moderators and mediators. Europe Journal Cancer Care, 20(5):610-619.

[26]. Fletcher, P.C. (2011). My child has cancer: finding the silver lining in every mother's nightmare. Issues Compr Pediatr Nurs, 34, 40-55.

[27]. Al-Momani, B.C. (2013). Informal social support: a collaborative stress management initiative for mothers of child with cancer. International Journal of Psychological Studies, 5, 19-31.

[28]. Han, H.R. (2003). Issues and innovations in nursing practice: Korean mother's psychosocial adjustment to Reviews their child's cancer. Journal of Advanced Nursing, 44, 499-506.

[29]. Pedro, I.C.S, Galvão, C.M., Rocha, S.M.M., Nascimento, L.C. (2008). 
Social support and families of children with cancer: an integrative review. Rev Latino-am Enfermagem maio-junho, 16(3):477-83.

[30]. Sarafino, E.P. (1998). Health psychology: biopsychosocial interactions. $3^{\text {rd }}$ ed. United States of America: John Wiley\&Sonc Inc 